DOI 10.37882/2223-2982.2020.06.08

\title{
ПРОБЛЕМА ОПРЕДЕЛЕНИЯ ПОНЯТИЯ АДВОКАТСКОЙ ДЕЯТЕЛЬНОСТИ КАК ФОРМЫ КВАЛИФИЦИРОВАННОЙ ЮРИДИЧЕСКОЙ ПОМОЩИ
}

\section{THE PROBLEM OF DEFINING THE CONCEPT OF ADVOCACY AS A FORM OF QUALIFIED LEGAL ASSISTANCE}

A. Vorob'ev

Summary: The article uses legal analysis to define the concept of advocacy as intermediary qualified legal assistance, the main purpose of which is to achieve judicial protection of the attorney's clients. The insufficient level of research on the right to qualified legal assistance has led to the fact that there are disputes in the scientific and educational literature about the definition of this constitutional right due to the vagueness of the criteria for the proposed definitions. In practice, legal assistance may be provided by non-lawyers in proceedings before magistrates and district courts in civil cases. The article offers criteria for distinguishing legal aid from qualified legal aid, and by legally fixing the concept of qualified legal aid, the solution to the problem of the lack of this concept is justified.

Keywords: legal practice, lawyer, qualified legal assistance.
B Основном Законе Российской Федерации - Конституции РФ [1] в ч. 1 ст. 46 установлена гарантия судебной защиты прав и свобод человека и гражданина. В ч. 1 ст. 48 Конституции РФ закреплена гарантия получения каждым лицом квалифицированной юридической помощи, в том числе и в бесплатном порядке. В ч. 1 ст. 1 Ф3 «Об адвокатской деятельности и адвокатуре в Российской Федерации» [2] дано понятие адвокатской деятельности. Адвокатской деятельностью является квалифицированная юридическая помощь, оказываемая на профессиональной основе лицами, получившими статус адвоката в порядке, установленном Законом об адвокатуре, физическим и юридическим лицам в целях защиты их прав, свобод и интересов, а также обеспечения доступа к правосудию. Из указанной дефиниции можно выделить следующие признаки адвокатской деятельности:

1. это квалифицированная юридическая помощь;

2. это профессиональная помощь;

3. данную помощь могу оказывать лица, получившие в установленном законе порядке статус адвоката;

4. защита прав, свобод и интересов, а также обеспечения доступа к правосудию доверителей (физических лиц и юридических лиц).
Воробьев Александр Сергеевич

Адвокат, аспирант, Всероссийский государственный университет юстиции (РПА Минюста РФ), г. Москва

advokat_lex@bk.ru

Аннотация: В статье посредством правового анализа определяется понятие адвокатской деятельности как посреднической квалифицированной юридической помощи, основной целью которой является достижение судебной защиты доверителей адвоката. Недостаточный уровень исследования права на квалифицированную юридическую помощь привел к тому, что в научной и учебной литературе имеются споры по поводу определения данного конституционного права в связи с размытостью критериев предлагаемых дефиниций. На практике юридическую помощь могут оказывать неюристы при производстве у мировых судей и в районных судах по гражданским делам. В статье предлагаются критерии разграничения юридической помощи от квалифицированной юридической помощи, а также путём легального закрепления понятия квалифицированной юридической помощи обосновывается решение проблемы отсутствия данного понятия.

Ключевые слова: адвокатская деятельность, адвокат, квалифицированная юридическая, помощь.

Стоит отметить, что легального определения «квалифицированная юридическая помощь» в настоящее время не существует. В научной литературе также отсутствует единое понимание данного термина. По нашему мнению, подобный правовой пробел нуждается в разрешении, поскольку отсутствует единое понимание какая деятельность является квалицированной юридической помощью.

Представляется, что для более точного определения указной дефиниции необходимо разбить данное конституционное право на два разных термина: «квалифицированный» и «юридическая помощь». Рассмотрим их по отдельности.

Наиболее распространенным в науке является определение юридической помощи как активной профессиональной деятельности лиц, обладающих специальными познаниями в области права, направленной на защиту потенциально нарушаемых или реально нарушенных прав, свобод и охраняемых законом интересов физических и юридических лиц [6, с. 15]. В.С. Кашковский рассматривает юридическую помощь как «помощь, оказываемую в результате осуществления профессиональной деятельности юриста, основной целью которой является 
необходимое содействие в предупреждении нарушения прав, свобод и законных интересов субъектов права, устранении или уменьшении неблагоприятных последствий такого нарушения и восстановлении надлежащего положения субъекта права» [4, с. 36]. С точки зрения А.В. Закомолдина, квалифицированная юридическая помощь - «это деятельность определенных нормами международного и внутригосударственного права субъектов - профессиональных юристов, заключающаяся в установлении смысла нормативно-правовых установлений и совершении юридических и фактических действий, направленных на защиту или восстановление прав, свобод и законных интересов каждого» [3, с. 5]. Шереметова Г.С., из проделанного анализа в своей работе, делает вывод, что квалифицированная юридическая помощь - «это невластное адресное содействие профессиональных субъектов - юристов иным лицам, которое носит публично-правовой характер, целью которого является обеспечение прав, свобод и законных интересов лиц, а также их защита в установленном законом порядке» [7].

Из приведенных определений можно выделить следующие признаки юридической помощи:

- Данная деятельность осуществляется специальными субъектами права, получившими высшее юридическое образование, то есть юристами;

- Данная деятельность носит целевой характер, направленная на обеспечение, защиту и восстановление прав, свобод и законных интересов лиц;

- Юридическая помощь направлена на конкретного адресата, нуждающегося в юридической помощи;

- Юридическая помощь - это право нуждающегося лица, а не его обязанность, поэтому эта деятельность не носит публично-правовой характер;

- Юридическая помощь - это система мер и средств, таких как консультирование, представительство в судах, государственных и иных организациях, правовой аудит и другое;

- Юридическая помощь - это механизм, установленных и гарантированных государством с целью эффективной реализации, защиты и восстановле- ния прав, свобод и законных интересов гражданами через правосудие, правоохранительные органы и пр.

Понятие «квалифицированный» означает: «имеющий высокую квалификацию, опытный, требующий специальных знаний» [5, с. 229]. Под квалификацией в широком смысле этого слова понимается: степень годности к какому-либо виду труда, уровень подготовленности, профессия, специальность [5, с. 229]. Поэтому на наш взгляд, необходимо разделять понятия «квалифицированная юридическая помощь» и «юридическая помощь», так как первое понятие это базовое конституционное право, гарантируемое государством каждому обрившемся юристу, нотариусу, адвокату, государственному, муниципальному или иному органу за получением юридической консультации, за защитой нарушенных прав, за юридическим закреплением субъективных прав и предупреждением их возможного нарушения в будущем, обладающие специальной квалификацией по разрешению данных вопросов, подтверждаемые наличием образования и учеными степенями, статусом, званием и пр., а юридическую помощь может оказывать лицо, обладающее только соответствующим образованием, без квалификаций. Более того, юридическую помощь у мировых судей, а также в районных судах по гражданским делам может оказывать лицо, не обладающее ни юридическим образованием.

Таким образом, резюмируя вышеизложенное отметим, что в настоящее время отсутствует понятие квалифицированной юридической помощи, что является серьёзным пробелом. В результате нашего исследования, мы пришли к выводу, что квалифицированная юридическая помощь - это помощь юристов, обладающих определенной квалификацией в сфере обеспечения, защиты и восстановления прав, свобод и законных интересов граждан, подтвержденной наличием образования в данной сфере, статусом, ученой степенью, званием и пр. Эта помощь является базовым конституционным правом, которое принадлежит каждому человеку от рождения. Представляется, что необходимо законодательно определить понятие указанного термина с целью устранения существующих противоречий.

\section{ЛИТЕРАТУРА}

1. «Конституция Российской Федерации» принята всенародным голосованием 12.12.1993 (с учетом поправок, внесенных Законами РФ о поправках к Конституции РФ от 30.12.2008 N 6-ФКЗ, от 30.12.2008 N 7-ФК3, от 05.02.2014 N 2-ФК3, от 21.07.2014 N 11-ФКЗ) в «Собрании законодательства РФ», 04.08.2014, N31, ст. 4398.

2. 06 адвокатской деятельности и адвокатуре в Российской Федерации: Федеральный закон от 31.05.2002 N 63-Ф3 // «Собрание законодательства РФ», 10.06.2002, N 23, ст. 2102.

3. Закомолдин А.В. Квалифицированная юридическая помощь в уголовном процессе России: понятие, содержание, гарантии: Автореф. дис. ... канд. юрид. наук. Самара, 2007. 
4. Кашковский В.С. Юридическая помощь как правовая категория и социально-правовое явление: вопросы теории и практики: Дис. ... канд. юрид. наук. Тамбов, 2009.

5. Ожегов С.И. Толковый словарь русского языка: Ок. 100000 слов, терминов и фразеологических выражений / Под ред. проф. Л.И. Скворцова - 27 изд., испр. - Москва: Мир и образование, 2018.

6. Черняков И.Г. Реализация конституционного права на квалифицированную юридическую помощь в Российской Федерации: проблемы и перспективы: Автореф. дис. ... канд. юрид. наук. Челябинск, 2007.

7. Шереметова Г.С. Право на бесплатную юридическую помощь в гражданском процессе. М.: Статут, 2015. 176 с.// «Консультант Плюс».

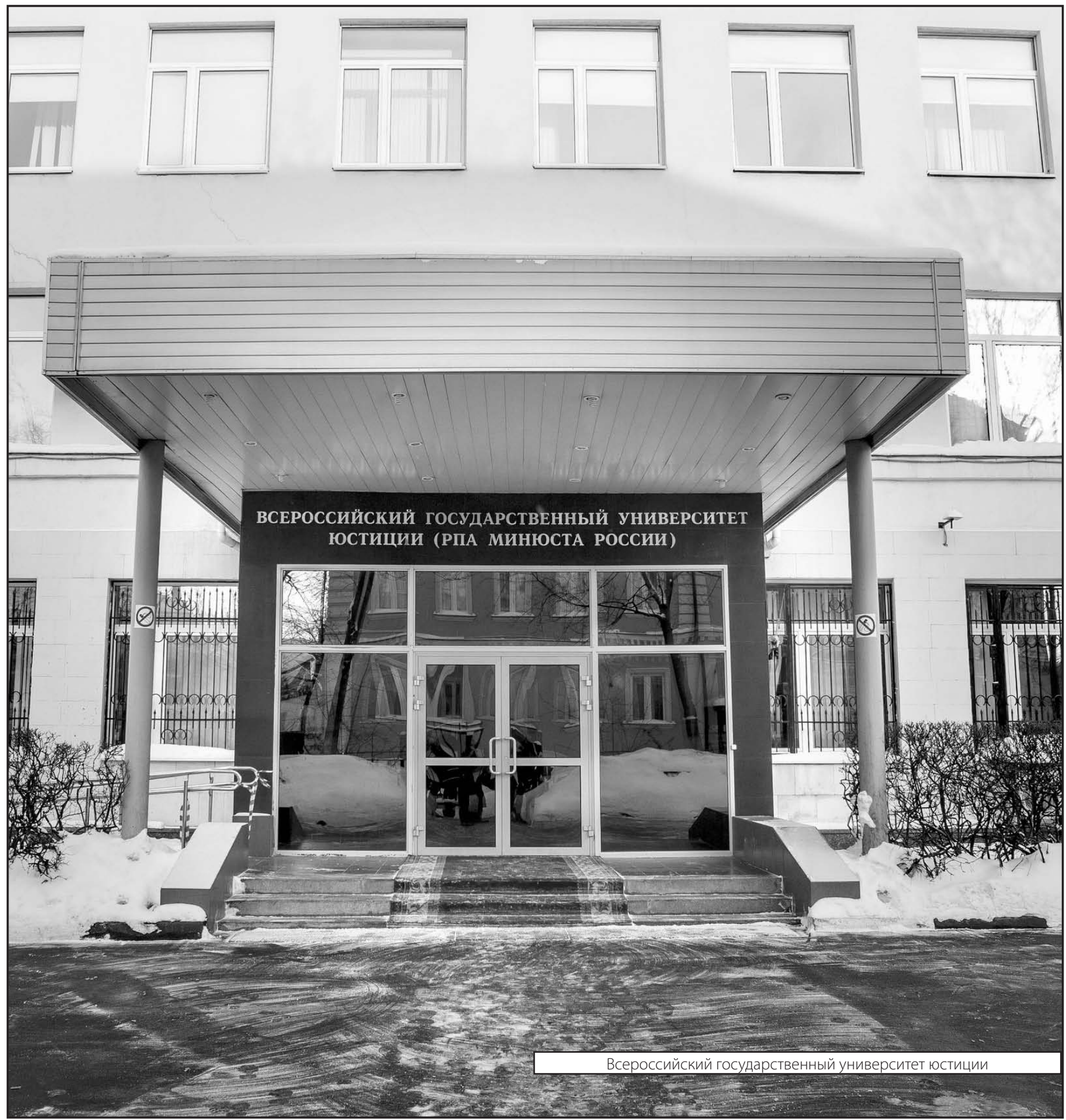

